\title{
PERLINDUNGAN ANAK KORBAN KEKERASAN SEKSUAL MELALUI PENDEKATAN KEADILAN RESTORATIF
}

\author{
Nurini Aprilianda \\ Fakultas Hukum Universitas Brawijaya \\ Jl. M.T. Haryono 169 Malang \\ Email: aprilianda@yahoo.co.id
}

\begin{abstract}
The aim of this paper is analyze the suitability between the protection of children as victims of sexual crimes as regulated in Act number 35/2014 on the Amendment of Act number 23/2002 on Child Protection relating to the handling of child victims of sexual abused with a restorative justice approach as set in Act Number 11/2012 on the Juvenile Criminal Justice System. This paper based on normative legal research. The results of the study indicate that the protection of children as victims of sexual violence in Article 71D of Act Number 35/2014 on the Amendment of Act Number 23/2002 on Child Protection has not fully reflect the handling with restorative justice approach.
\end{abstract}

Key words: child protection, sexual abused, restirative justice

\begin{abstract}
Abstrak
Tulisan ini bertujuan untuk menganalisis terkait kesesuaian antara perlindungan anak korban kejahatan seksual yang diatur dalam UU 35/2014 mengenai Perubahan atas UU 23/2002 tentang Perlindungan Anak terkait penanganan anak sebagai korban kekerasan seksual dengan pendekatan keadilan restoratif sebagaimana diatur dalamUU 11/2012 mengenai Sistem Peradilan Pidana Anak. Untuk menjawab tujuan tulisan tersebut, digunakan penelitian hukum normatif dengan menggunakan pendekatan undang-undang. Hasil penelitian tersebut menunjukkan bahwa pengaturan perlindungan terhadap anak sebagai korban kekerasan seksual dalam Pasal 71D UU 35/2014 mengenai Perubahan terhadap UU 23/2002 tentang Perlindungan Anak belum sepenuhnya mencerminkan penanganan dengan menggunakan pendekatan keadilan restoratif.
\end{abstract}

Kata kunci: perlindungan pada anak, korban kekerasan seksual, keadilan restoratif

\section{Latar Belakang}

Pentingnya perlindungan hukum terhadap korban kejahatan secara memadai tidak hanya menjadi isu nasional, melainkan juga menjadi isu internasional.Oleh karena itu, masalah ini harus mendapat perhatian yang serius. Hal ini dapat dilihat dari dibentuknya Declaration of
Basic Principles of Justice for Victims of Crime and Abuse Power oleh Perserikatan BangsaBangsa (PBB), sebagai hasil dari The Seventh United Nation Conggres on the Prevention of Crime and The Treatment of Offenders, yang berlangsung di Milan, Italia, September 1985. Dalam salah satu rekomendasinya disebutkan: 
"Offenders or third parties responsible for their behavior should, where appropriate, make fair restitution to victims, their families or dependants. Such restitution should include the return of property or payment for the harm or loss suffered, reimbursement of expenses incurred as a result of the victimization, the provision of services and the restoration of the rights." Dalam deklarasi di Milan pada Tahun 1985 tersebut, bentuk perlindungan yang diberikan mendapat perluasan yang tujuannya tidak hanya ditujukan pada korban kejahatan (victim of crime), tetapi juga perlindungan pada korban karena adanya penyalahgunaan kekuasaan (abuse of power). ${ }^{1}$

Di Indonesia, masalah terkait perlindungan pada korban kejahatan juga harus mendapatkan perhatian yang serius. Hal ini disikapi oleh pemerintah dengan cara mengerluarkan Undang-undang Nomor 13 Tahun 2006 mengenai Perlindungan Saksi dan Korban. Namun, dengan berjalannya waktu, UU tersebut dianggap mempunyai beberapa kelemahan yang di nilai cukup signifikan, sehingga perlu dilakukan perubahan terhadap UUtersebut. ${ }^{2}$ Undang-undang Nomor 31 Tahun 2014 yang merupakan Perubahan atas UU No. 13 Tahun 2006 mengenai Perlindungan Saksi dan Korban yang disahkan oleh Pemerintah dan diundangkan untuk memperbaiki kelemahan pada UU No. 13 Tahun 2006.
Khusus untuk perlindungan hukum terhadap anak, negara memberikan perhatian dengan mengesahkan Undang-undang Nomor 35 Tahun 2014 yang merupakan Perubahan atas Undang-undang Nomor 23 Tahun 2002 mengenai Perlindungan Anak. Perubahan tersebut adalah untuk mempertegas tentang pentingnya pemberatan sanksi pidana dan juga denda bagi pelaku kejahatan terhadap anak untuk memberikan efek jera, serta untuk mendorong adanya langkah konkret untuk memulihkan kembali secara fisik, psikis dan juga sosial anak sebagai korban dan atau anak sebagai pelaku kejahatan sebagai langkah antisipatif supaya anak sebagai korban atau sebagai pelaku tidak menjadi pelaku kejahatan yang sama di kemudian hari. ${ }^{3}$

Penanganan perkara anak di Indonesia berdasarkan pada Undang-undang Nomor 11 Tahun 2012 mengenai Sistem Peradilan Pidana Anak (selanjutnya disebut UU SPPA). Dalam Pasal 5 (1) pada UU SPPA ditegaskan bahwa pada sistem peradilan pidana anak wajib mengutamakan pendekatan keadilan restoratif. Pada ayat berikutnya menegaskan bahwa, sistem peradilan pidana anak yang sebagaimana diatur dalam ayat (1) meliputi:

1 Penyidikan dan penuntutan dalam Sistem Pidana Anak yang dilaksanakan sesuai dengan ketentuan pada peraturan perundang-undangan, kecuali ditentukan lain dalam undang-undang ini;

1 Didik M Arif Mansur, Elisatris Gultom, Urgensi Perlindungan Korban Kejahatan Antara Norma dan Realita, (Jakarta: Rajawali Pers, 2006), hlm. 23.

2 Penjelasan Undang-Undang Republik Indonesia Nomor 35 Tahun 2014 tentang Perubahan Atas Undangundang Nomor 13 Tahun 2006 tentang Perlindungan Saksi dan Korban.

3 Penjelasan Undang-Undang Republik Indonesia Nomor 31 Tahun 2014 tentang Perubahan Atas Undangundang Nomor 23 Tahun 2002 tentang Perlindungan Anak. 
2 Persidangan Anak yang dilakukan oleh pihak pengadilan di lingkungan peradilan umum; dan

3 Pembinaan, pembimbingan, pengawasan dan atau pendampingan dalam proses pelaksanaan pidana atau tindakan dan pada saat setelah menjalani pidana atau tindakan dan juga saat setelah menjalani pidana atau tindakan.

Bila dicermati lebih lanjut, ketentuan penyelesaian perkara anak menggunakan pendekatan keadilan restoratif dalam Pasal 5 UU SPPA hanya berlaku bagi anak sebagai pelaku dan juga anak sebagai korban. Namun demikian pada undang-undang ini hanya berlaku bagi anak sebagai korban, anak sebagai pelaku dan juga anak sebagai saksi. Bila pelakunya adalah adalah orang dewasa dan korbannya adalah anak, UU SPPA tidak dapat diterapkan. Dalam hal pelaku adalah orang dewasa dengan korban anak maka diterapkan UU No. 31 Tahun 2014 mengenai Perubahan pada UU No. 13 Tahun 2006 mengenai Perlindungan Saksi dan Korban dan juga UU No. 35 Tahun 2014 mengenai Perubahan UU No. 23 Tahun 2002 mengenai Perlindungan Anak.

Namun demikian setelah beberapa undang-undang disahkan, fakta menunjukkan bahwa perubahan undang-undang masih jauh dari harapan. Berdasarkan catatan Komnas Perlindungan Anak (KPA) pada bulan Januari-April Tahun 2014 terdapat 342 mengenai kasus kekerasan seksual pada anak. Sementara data Polri pada Tahun
2014, mencatat ada 697 mengenai kasus kekerasan seksual pada anak yang terjadi di separuh Tahun 2014. Dari jumlah itu, sudah ada 726 orang yang telah ditangkap dengan jumlah korban mencapai hingga 859 orang. Sementara itu data Komisi Perlindungan Anak Indonesia (KPAI) mencatat pada Tahun 2013, jumlah kekerasan dan pelecehan seksual pada anak telah mencapai hingga 566 kasus. Tahun berikutnya jumlahnya melonjak hingga 1.267 kasus. Setelah ada wacana kebiri, kasus pelecehan seksual pada anak menjadi menurun drastis pada Tahun 2015, yakni 900 kasus. ${ }^{4}$ Jumlah anak sebagai korban dari kejahatan seksual menunjukkan suatu kondisi yang cukup memprihatinkan.

Permasalahan dalam tulisan ini adalah, sebagaimana berikut:

1. Apakah pengaturan perlindungan anak sebagai korban kejahatan seksual pada UU No. 35 Tahun 2014 mengenai perubahan atas UU No. 23 Tahun 2002 yang mencerminkan penanganan dengan menggunakan pendekatan keadilan restoratif seperti diamanahkan dalam UU SPPA?

2. Bagaimanakah perlindungan anak sebagai korban kejahatan seksual yang mencerminkan penanganan dengan pendekatan keadilan restoratif?

Untuk menjawab permasalahan diatas, digunakan penelitian hukum normatif dengan pendekatan peratura perundang-undangan.

4 Komisi Perlindungan Anak Indonesia, "Indonesia Darurat Kejahatan Seksual Anak", http://www.kpai.go.id/ berita/indonesia-darurat-kejahatan-seksual-anak/, diakses 20 Januari 2017. 
Dalam hal ini dilakukan dengan menganalisis ketentuan hukum dalam UU No. 11 Tahun 2012 tentang SPPA, UU No. 35 Tahun 2014 jo UU No. 23 Tahun 2002, UU No. 31 Tahun 2014 jo UU No. 13 Tahun 2006. Langkah berikutnya adalah melakukan sistemisasi, interpretasi sistematis, dan analisa serta evaluasi bahan-bahan hukum, baik dari segi substansi maupun relevansi substansinya. Analisa dilakukan secara yuridis dengan menerapkan metode berpikir deduktif.

\section{Pembahasan}

\section{A. Kesesuaian Penanganan Anak} Korban Kejahatan Seksual dengan Pendekatan Keadilan Restoratif dalam UU No. 35 Tahun 2014 mengenai Perubahan atas UU No. 23 Tahun 2002 mengenai Perlindungan Anak dengan UU No. 11 Tahun 2012 mengenai Sistem Peradilan Pidana Anak

Anak yang menjadi korban sebuah tindak pidana yang pada selanjutnya disebut Anak Korban adalah anak yang belum berusia 18 (delapan belas) tahun yang membuat anak mengalami penderitaan fisik, penderitaan mental, dan/atau kerugian ekonomi yang disebabkan oleh suatu tindak pidana. ${ }^{5}$ Anak sebagai korban dapat menderita kerugian fisik maupun kerugian non-fisik. Kerugian fisik dapat berupa cacat, luka-luka bahkan juga sampai kematian. Kerugian non-fisik dapat berupa mental anak yang terganggu, maupun rasa takut yang tidak ada hentinya yang dirasakan oleh anak. Mattalata, ${ }^{6}$ berpendapat bahwa usaha berupa pemberian bantuan pada korban bukanlah kewajiban untuk pelaku saja, melainkan juga kewajiban untuk warga masyarakat dan juga kewajiban negara. Perlindungan korban sebagai suatu upaya memberikan perlakuan yang adil baik bagi anak sebagai korban, pelaku maupun bagi masyarakat yang merupakan harapan yang dicita-citakan juga.

Korban dari suatu tindak pidana yang pada dasarnya adalah pihak yang paling menderita pada suatu tindak pidana, justru tidak mendapatkan perlindungan sebanyak yang diberikan Undang-Undang pada pelaku suatu kejahatan sebagaimana dikemukakan oleh Andi Hamzah, "Dalam membahas hukum acara pidana yang khususnya yang berkaitan pada hak-hak asasi manusia, ada kecenderungan untuk mengupas mengenai hal-hal yang berkaitan dengan hak-hak tersangka tanpa memperhatikan pula hak-hak korban suatu tindak pidana." Rendahnya kedudukan korban suatu tindak pidana dalam penanganan perkara pidana, hal ini juga dikemukakan oleh Prassell yang menyatakan: "Victim was a forgotten figure in study of

5 Undang-undang Nomor 11 Tahun 2012 tentang Sistem Peradilan Pidana Anak, Pasal 1, ayat 4.

6 Yazid Effendi, op.cit., hlm. 37.

7 Andi Hamzah, Perlindungan Hak-hak Asasi Manusia dalam Kitab Undang-Undang Hukum Acara Pidana, (Bandung: Binacipta, 1986), hlm. 33.

8 Haryanto Dwiatmodjo, "Pelaksanaan Perlindungan Hukum Terhadap Anak yang Menjadi Korban Tindak Pidana di Wilayah Hukum Pengadilan Negeri Banyumas", Jurnal Dinamika Hukum, Vol. 11, No. 2, (Mei 2011): 202. 
crime. Victims of assault, robbery, theft and other offences were ignored while police, courts, and academicians concentrated on known violators ". ${ }^{8}$ Perlindungan hukum pada korban kejahatan merupakan bagian dari perlindungan masyarakat, dapat diwujudkan melalui berbagai bentuk, misalnya seperti melalui pemberian restitusi dan kompensasi pada korban, pelayanan medis, dan juga berupa bantuan hukum. ${ }^{9}$

Ganti rugi adalah sesuatu yang diberikan pada pihak yang menderita atau mengalami kerugian sepadan dengan memperhitungkan kerusakan yang dideritanya. ${ }^{10}$ Perbedaan antara kompensasi dan juga restitusi ${ }^{11}$ adalah "kompensasi timbul berasal permintaan korban suatu tindak pidana, dan dibayar oleh masyarakat atau merupakan suatu bentuk pertanggungjawaban dari masyarakat atau dari negara (The responsible of the society), sedangkan restitusi lebih bersifat pada pidana, yang timbul dari putusan pengadilan terkait perkara pidana dan dibayar oleh terpidana atau merupakan wujud pertanggungjawaban dari terpidana. ${ }^{12}$

Perlindungan korban dapat mencakup bentuk perlindungan yang bersifat abstrak (tidak langsung) maupun yang konkret (langsung). Perlindungan yang abstrak pada dasarnya merupakan bentuk perlindungan yang hanya bisa dinikmati atau dirasakan secara emosional (psikis), seperti rasa puas (kepuasan). Perlindungan yang kongkrit pada dasarnya merupakan bentuk perlindungan yang dapat dinikmati secara nyata, seperti pemberian yang berupa atau bersifat materi maupun non-materi.

Perlindungan pada korban di dalam sistem peradilan pidana, pada awalnya tercantum dalam KUHAP, yaitu Pasal 98 sampai dengan Pasal 101 KUHAP. Namun demikian dalam KUHAP hanya sebatas tentang penggabungan perkara saja. Yang intinya dalam perkembangannya, KUHAP kurang dapat memberikan perlindungan bagi korban secara utuh, padahal keberadaan saksi dan atau korban suatu tindak pidana dalam hal ini sangat diperlukan dan juga merupakan suatu hal yang harus sangat diperhatikan sebagai satu kesatuan di dalam proses pemeriksaan dalam peradilan pidana. Saksi adalah alat bukti utama yang telah ditegaskan dalam Pasal 184 KUHAP, yang menyebutkan:

1. Alat bukti yang sah yaitu, sebagai berikut:

2. Keterangan saksi;

3. Keterangan ahli;

4. Surat;

5. Petunjuk;

6. Keterangan terdakwa

Urutan tersebut bukan hanya urutan,

9 Dikdik. M. Arief Mansur, op.cit., hlm. 31.

10 Jeremy Bentham, Teori Perundang-Undangan Prinsip-Prinsip Legislasi, Hukum Perdata dan Hukum Pidana, (Bandung: Penerbit Nusamedia \& Penerbit Nuansa, 2006), hlm. 316.

11 Dowden, C., \& Andrews, D. A., "Effective correctional treatment and violent re-offending: A meta-analysis", Canadian Journal of Criminology 42, (2000): 449-476.

12 Haryanto Dwiatmodjo, op.cit., hlm. 203. 
tetapi juga menggambarkan tingkat kekuatan pembuktian, sehingga saksi merupakan alat bukti yang memiliki kekuatan pembuktian utama.

Pada prinsipnya perlindungan akan hak-hak seseorang sebagai saksi telah diakomodasikan dalam KUHAP, tetapi mengingat jenis tindak pidana yang semakin beragam dan menimbulkan efek atau akibat bagi keselamatan jiwa dari saksi/korban atau keluarganya, pada Tahun 2006 pemerintah Indonesia mengeluarkan UU Nomor 13 Tahun 2006 mengenai Perlindungan Saksi dan Korban. Di dalam Undang-undang Nomor 13 Tahun 2006 mengenai Perlindungan Saksi dan Korban tersebut telah diatur mengenai berbagai hak yang diberikan oleh Negara pada korban suatu tindak pidana yang sebelumnya belum atau tidak diatur dalam KUHAP. Adapun hak-hak korban dicantumkan pada Pasal 5 UU No. 13 Tahun 2006 dikutip sebagai berikut:

1 Memperoleh perlindungan berupa keamanan pribadi, keluarga, dan juga harta bendanya, serta bebas dari ancaman-ancaman yang berkenaan dengan kesaksian yang akan, sedang, atau telah diberikan oleh korban.

2 Ikut serta selama proses memilih dan menentukan bentuk- bentuk perlindungan dan juga dukungan keamanan.

3 Memberikan keterangan tanpa tekanan dari pihak siapapun.

4 Mendapatkan penerjemah.

5 Bebas dari pertanyaan-pertanyaan yang menjerat korban

6 Mendapatkan informasi yang berkaitan perkembangan kasus

7 Mendapatkan informasi yang berkaitan dengan putusan pengadilan

8 Mengetahui yang berkaitan dengan hal terpidana dibebaskan

9 Mendapatkan sebuah identitas baru

10 Memperoleh penggantian biaya untuk trasportasi sesuai dengan kebutuhan.

11 Mendapatkan penasihat hukum untuk korban

12 Memperoleh bantuan berupa biaya hidup sementara hingga batas waktu perlindungan berakhir.

13 Mendapatkan sebuah tempat kediaman baru.

Bentuk-bentuk sebuah perlindungan serta hak saksi dan juga korban diberikan sejak dimulainya tahap penyelidikan dan berakhir sesuai dengan ketentuan pada peraturan perundangan-undangan. Bahkan, jika dalam memberikan kesaksian di depan persidangan, karena kehadirannya akan membuat jiwanya terancam, undang-undang dalam hal ini akan memberikan perlindungan terhadap saksi atau terhadap korban atau pihak keluarga dengan cara melakukan kesaksian tanpa kehadirannya pelaku di pemeriksaan depan persidangan.

Namun tidak jarang seseorang yang mengalami kerugian baik secara materil maupun imeterill akibat suatu peristiwa tindak pidana yang telah menimpa dirinya, tidak mempergunakan hak-hak yang seharusnya di peroleh karena berbagai macam alasan, misalnya saja pada kejahatan seksual. Seseorang yang menjadi korban dari kejahatan seksual akan ada perasaan takut dikemudian hari apabila masyarakat menjadi tahu kejadian yang menimpa dirinya, karena suatu kejahatan seksual tersebut merupakan 
aib bagi dirinya maupun keluarganya juga bebas dari ancaman dapat mengungkap sehingga korban lebih baik menyembunyikan suatu tindak pidana yang kemudian untuk atau korban menolak untuk mengajukan ganti kerugian karena dikhawatirkan prosesnya akan menjadi semakin panjang dan berlarutlarut yang dapat berakibat pada timbulnya penderitaan yang berkepanjangan. ${ }^{13}$

Selanjutnya dijelaskan pula pada UU No. 13 Tahun 2006 bahwa seorang korban dalam pelanggaran hak asasi manusia yang berat, selain korban berhak atas hak sebagaimana dimaksud diatas juga berhak untuk mendapatkan: ${ }^{14}$

1. bantuan medis; dan juga

2. bantuan rehabilitasi psiko-sosial.

Kemudian dijelaskan pula dalam bagian berikutnya pada undang-undang mengenai Perlindungan Saksi dan Korban: ${ }^{15}$

1. hak untuk memperoleh suatu kompensasi dalam kasus pelanggaran HAM berat

2. hak untuk memperoleh restitusi atau ganti kerugian yang menjadi tanggung jawab pelaku tindak pidana ${ }^{16}$

Dalam perkembanganya, jaminan perlindungan pada saksi dan pada korban memiliki peranan yang sangat penting di dalam proses peradilan pidana sehingga dengan keterangan dari saksi dan korban yang diberikan secara bebas dari rasa takut dan meningkatkan suatu upaya pengungkapan secara menyeluruh suatu tindak pidana, khususnya pada tindak pidana transnasional yang telah terorganisasi, perlu juga diberikan perlindungan pada saksi pelaku, pelapor, dan juga ahli. Beberapa ketentuan pada Undangundang Nomor 13 Tahun 2006 mengenai Perlindungan Saksi dan Korban harus disesuaikan dengan perkembangan kebutuhan hukum dalam masyarakat. Oleh sebab itulah ditetapkannya Undang-Undang Republik Indonesia Nomor 31 Tahun 2014 mengenai Perubahan Atas Undang-undang Nomor 13 Tahun 2006 mengenai Perlindungan Saksi Dan Korban.

Di dalam UU Nomor 31 Tahun 2014 ini terdapat beberapa perubahan, termasuk terdapat perubahan atas Pasal 5 yang mengatur tentang hak-hak seorang saksi dan juga korban, perubahan tersebut menjadi sebagai berikut: ${ }^{17}$

1 mendapatkan perlindungan untuk keamanan pribadi, Keluarga, dan juga harta bendanya, serta bebas dari Ancaman yang berkenaan dengan kesaksiannya yang akan, sedang, atau telah diberikan;

2 ikut serta di dalam proses memilih dan juga menentukan bentuk perlindungan

13 Didik M Arif Mansur dan Elistaris Gultom, op.cit., hlm. 52.

14 Pasal 6 Undang-undang No 13 tahun 2006 tentang Perlindungan Saksi dan Korban.

15 Pasal 7 ayat (1) Undang-undang N0. 13 tahun 2006 tentang Perlindungan Saksi dan Korban.

16 PP No. 4 Tahun 2008 tentang Pemberian Kompensasi, Restitusi dan bantuan terhadap saksi dan korban, Restitusi adalah ganti kerugian yang diberikan kepada korban atau keluarganya oleh pelaku atau pihak ketiga, dapat berupa pengambilan harta milik, pembayaran ganti kerugian untuk kehilangan atau penderitaan atau penggantian biaya untuk tindakan tertentu.

17 Pasal 5 ayat (1) Undang-Undang Republik Indonesia Nomor 31 Tahun 2014 tentang Perubahan Atas Undangundang Nomor 13 Tahun 2006 tentang Perlindungan Saksi dan Korban. 
dan juga dukungan keamanan;

3 memberikan keterangan tanpa mendapat tekanan;

4 memperoleh penerjemah;

5 bebas dari pertanyaan-pertanyaan yang menjerat;

6 mendapatkan informasi yang berkaitan dengan perkembangan kasus;

7 mendapatkan informasi yang berkaitan dengan putusan pengadilan;

8 mendapatkan informasi dalam hal-hal terpidana dibebaskan;

9 dirahasiakan segala yang berkaitan dengan identitasnya;

10 mendapatkan sebuah identitas baru;

11 mendapatkan sebuah tempat kediaman sementara;

12 mendapatkan sebuah tempat kediaman baru;

13 memperoleh penggantian biaya untuk transportasi sesuai dengan kebutuhan;

14 mendapatkan nasihat hukum;

15 mendapatkan bantuan biaya hidup untuk sementara sampai batas waktu Perlindungan berakhir; dan/atau

16 mendapatkan pendampingan.

Hak-hak yang sebagaimana dimaksud diatas, akan diberikan kepada Saksi dan atau Korban suatu tindak pidana pada kasus tertentu sesuai dengan Keputusan Lembaga Perlindungan Saksi dan Korban (LPSK) ${ }^{18}$. Yang dimaksud dengan "tindak pidana dalam kasus tertentu" antara lain, adalah tindak pidana pelanggaran hak asasi manusia yang berat, tindak pidana dalam kasus korupsi, tindak pidana dalam kasus pencucian uang, tindak pidana dalam kasus terorisme, tindak pidana dalam kasus perdagangan orang, tindak pidana dalam kasus narkotika, tindak pidana dalam kasus psikotropika, tindak pidana seksual pada anak, dan tindak pidana dalam kasus lain yang mengakibatkan posisi Saksi dan/atau Korban dihadapkan dengan situasi yang sangat membahayakan jiwanya ${ }^{19}$.

Korban dalam kasus pelanggaran hak asasi manusia yang berat, Korban tindak pidana dalam kasus terorisme, Korban tindak pidana dalam kasus perdagangan orang, Korban tindak pidana dalam kasus penyiksaan, Korban tindak pidana dalam kasus kekerasan seksual, dan juga Korban dalam kasus penganiayaan berat, selain berhak sebagaimana dimaksud diatas juga berhak mendapatkan: ${ }^{20}$

1. berupa bantuan medis; dan juga

2. berupa bantuan rehabilitasi psikososial dan psikologis.

Yang dimaksud "bantuan medis" merupakan bantuan yang diberikan pada korban yang bertujuan memulihkan kesehatan fisik Korban, termasuk dalam melakukan pengurusan dalam hal Korban meninggal dunia misalnya dalam pengurusan jenazah hingga pemakaman. ${ }^{21}$ Bantuan medis juga dapat berupa sebuah pemeriksaan kesehatan

18 Pasal 5 ayat (2) Undang-Undang Republik Indonesia Nomor 31 Tahun 2014 tentang Perubahan Atas Undangundang Nomor 13 Tahun 2006 tentang Perlindungan Saksi Dan Korban.

19 Penjelasan Pasal 5 ayat (2) Undang-Undang Republik Indonesia Nomor 31 Tahun 2014 tentang Perubahan Atas Undang-undang Nomor 13 Tahun 2006 tentang Perlindungan Saksi Dan Korban.

20 Pasal 6 ayat (1) Undang-Undang Republik Indonesia Nomor 31 Tahun 2014 tentang Perubahan Atas Undangundang Nomor 13 Tahun 2006 tentang Perlindungan Saksi Dan Korban.

21 Penjelasan Pasal 6 ayat (1) Huruf a Undang-Undang Republik Indonesia Nomor 31 Tahun 2014 tentang Perubahan Atas Undang-undang Nomor 13 Tahun 2006 tentang Perlindungan Saksi Dan Korban. 
korban dan laporan tertulis (visum atau surat keterangan medis yang juga memiliki kekuatan hukum yang sama dengan dengan alat bukti). Keterangan medis diperlukan terutama untuk apabila koban hendak melaporkan kejahatan yang menimpa dirinya kepada aparat kepolisian untuk segera ditindak lanjuti. ${ }^{22}$ Yang dimaksud "rehabilitasi psikososial" merupakan semua bentuk pelayanan dan juga bantuan psikologis serta bantuan sosial yang ditujukan untuk membantu meringankan, membantu melindungi, dan juga membantu memulihkan kondisi fisik, kondisi psikologis, kondisi sosial, dan kondisi spiritual Korban sehingga dapat menjalankan fungsi sosialnya kembali dengan wajar, antara lain LPSK mempunyai upaya melakukan peningkatan kualitas hidup pada Korban dengan melakukan kerja sama dengan instansiinstansi terkait yang berwenang berupa bantuan pemenuhan sandang, pangan, papan, bantuan mendapatkan pekerjaan, atau bantuan kelangsungan pendidikan pada korban. Yang dimaksud "rehabilitasi psikologis" merupakan bantuan yang diberikan dari psikolog kepada Korban yang menderita rasa trauma atau masalah kejiwaan lainnya dengan tujuan untuk memulihkan kembali keadaan kejiwaan Korban. ${ }^{23}$

Setiap Korban dalam kasus pelanggaran hak asasimanusia yang berat dan Korban tindak pidana kasus terorisme selain mendapatkan hak sebagaimana diatas juga berhak mendapatkan Kompensasi. ${ }^{24}$ Kompensasi bagi Korban kasus pelanggaran hak asasi manusia yang berat diajukan oleh pihak Korban, Keluarga, atau kuasanya kepada Pengadilan Hak Asasi Manusia dengan cara melalui LPSK. $^{25}$ Pelaksanaan pembayaran untuk Kompensasi yang dijelaskan diatas diberikan dari LPSK berdasarkan putusan pengadilan yang telah mendapatkan kekuatan hukum tetap ${ }^{26}$. Pendanaan yang diperlukan untuk melakukan pembayaran sebagai Kompensasi korban dibebankan pada anggaran LPSK. ${ }^{27}$ Pemberian Kompensasi bagi Korban tindak pidana kasus terorisme dilaksanakan sesuai dengan ketentuan undang-undang yang mengatur berkaitan dengan pemberantasan tindak pidana terorisme. ${ }^{28}$

Selain Kompensasi, korban juga berhak untuk memperoleh hak Restitusi berupa: ${ }^{29}$

22 Didik M Arif Mansur dan Elistaris Gultom, op.cit., hlm. 171.

23 Penjelasan Pasal 6 ayat (1) Huruf b Undang-Undang Republik Indonesia Nomor 31 Tahun 2014 tentang Perubahan Atas Undang-undang Nomor 13 Tahun 2006 tentang Perlindungan Saksi Dan Korban.

24 Pasal 7 ayat (1) Undang-Undang Republik Indonesia Nomor 31 Tahun 2014 tentang Perubahan Atas Undangundang Nomor 13 Tahun 2006 tentang Perlindungan Saksi Dan Korban.

25 Pasal 7 ayat (2) Undang-Undang Republik Indonesia Nomor 31 Tahun 2014 tentang Perubahan Atas Undangundang Nomor 13 Tahun 2006 tentang Perlindungan Saksi Dan Korban.

26 I Pasal 7 ayat (3) Undang-Undang Republik Indonesia Nomor 31 Tahun 2014 tentang Perubahan Atas Undangundang Nomor 13 Tahun 2006 tentang Perlindungan Saksi Dan Korban.

27 Penjelasan Pasal 7 ayat (2) Undang-Undang Republik Indonesia Nomor 31 Tahun 2014 tentang Perubahan Atas Undang-undang Nomor 13 Tahun 2006 tentang Perlindungan Saksi Dan Korban.

28 Pasal 7 ayat (4) Undang-Undang Republik Indonesia Nomor 31 Tahun 2014 tentang Perubahan Atas Undangundang Nomor 13 Tahun 2006 tentang Perlindungan Saksi Dan Korban.

29 Pasal 7 A ayat (1) Undang-Undang Republik Indonesia Nomor 31 Tahun 2014 tentang Perubahan Atas Undang-undang Nomor 13 Tahun 2006 tentang Perlindungan Saksi Dan Korban. 
1. ganti kerugian atas kehilangan kekayaan korban atau penghasilan korban;

2. ganti kerugian yang ditimbulkan karena penderitaan yang berkaitan secara langsung sebagai dampal tindak pidana; dan/atau

3. penggantian suatu biaya perawatan medis dan/atau biaya psikologis.

Berdasarkan uraian di atas, korban kekerasan seksual selain korban berhak mendapatkan hak-haknya yang secara umum diatur dalam Pasal 5 UU No. 31 Tahun 2014 juga berhak mendapatkan sebuah bantuan medis, rehabiltasi, kompensasi dan juga restitusi.

Selain KUHAP dan UU No. 31 Tahun 2014, apabila korban adalah anak, maka penanganan anak sebagai korban secara umum diatur dalam UU 11/2002 mengenai Sistem Peradilan Pidana Anak (UU SPPA). Memberikan perlindungan pada anak sebagai korban kejahatan adalah salah satu dari tujuan sistem peradilan pidana anak. ${ }^{30}$ Di dalam UU No. 11 Tahun 2012 mengenai SPPA, Anak sebagai korban tindak pidana disebut sebagai Anak Korban. ${ }^{31}$ Berikut ini akan di sebutkan mengenai hal-hal yang berkaitan dengan Anak Korban yang telah diatur di dalam UU No. 11 Tahun 2012 tentang SPPA.

Di dalam proses peradilan pidana, Anak sebagai Korban berhak untuk mendapatkan untuk indentitasnya dirahasiakan dalam pemberitaan di media cetak ataupun di media elektronik. ${ }^{32}$ Identitas Anak sebagai Korban hanya boleh diberitakan atau dipublikasikan hanya dengan menggunakan inesial tanpa gambar. ${ }^{33}$ Apabila hal ini dilanggar, ada konsekuensi besar yang harus ditanggung. Tidak main-main, sanksi pidana penjara paling lama adalah 5 (lima) tahun dan denda paling banyak adalah Rp. 500.000.000,00 (lima ratus juta rupiah) telah menunggu bagi yang melanggar hak Anak Korban yang satu ini. $^{34}$

UU No. 11 Tahun 2012 mengenai SPPA juga memberikan hak terhadap Anak Korban untuk ikut serta dalam proses diversi. ${ }^{35}$ Pada proses diversi yang wajib dilakukan dengan pendekatanakan restorative justice ini juga harus disetujui oleh Anak Korban. Namun juga terdapat ketentuan terkait persetujuan Anak Korban pada proses diversi tersebut, ketentuan tersebut ialah bahwa pada kesepakatan Diversi harus mendapatkan persetujuan korban dan/atau keluarga Anak sebagai Korban serta kesediaan Anak dan keluarganya, kecuali untuk: ${ }^{36}$
a. tindak pidana berupa pelanggaran;
b. tindak pidana yang ringan;
c. tindak pidana tanpa korban; atau

\footnotetext{
30 Rena Yulia, op.cit., hlm. 62.

31 Pasal 1 angka 6 UU. No. 11 tahun 2012 tentang Sistem Peradilan Pidana Anak.

32 Pasal 3 huruf I dan Pasal 19 ayat (1) UU No. 11 Tahun 2012 tentang SPPA.

33 Pasal 61 ayat (2) UU No. 11 Tahun 2012 tentang SPPA.

34 Pasal 97 UU No. 11 Tahun 2012 tentang SPPA.

35 Pasal 8 ayat (1) UU No. 11 Tahun 2012 tentang SPPA.

36 Pasal 9 ayat (2) UU No. 11 Tahun 2012 tentang SPPA.

37 Pasal 23 ayat (2) UU No. 11 Tahun 2012 tentang SPPA.
} 
d. nilai kerugian korban tidak lebih dari nilai upah minimum dalam provinsi setempat

Anak Korban juga mempunyai hak untuk didampingi oleh orang tua dan/atau orang yang dipercaya oleh Anak Korban dan/atau Anak Saksi, atau Pekerja Sosial dalam setiap tingkat pemeriksaan $^{37}$. Pada tingkat pemeriksaan dalam persidangan, dalam hal-hal tertentu Anak sebagai Korban diberi kesempatan oleh Hakim untuk menyampaikan pendapat mengenai perkara yang bersangkutan. ${ }^{38}$

Anak korban juga berhak atas: ${ }^{39}$

a. upaya rehabilitasi medis dan juga rehabilitasi sosial, baik di dalam lembaga maupun juga di luar lembaga;

b. jaminan untuk keselamatan, baik fisik, mental, maupun keselamatan sosial; dan

c. kemudahan untuk mendapatkan informasi yang berkaitan dengan perkembangan perkara.

Untuk mendapatkan hak rehabilitasi medis, rehabilitasi sosial, dan juga reintegrasi sosial dari lembaga atau instansi yang menangani hal-hal pelindungan anak, harus didasarkan pada hasil dari Penelitian Kemasyarakatan dari Pembimbing Kemasyarakatan dan laporan sosial dari Pekerja Sosial Profesional atau Tenaga Kesejahteraan Sosial. ${ }^{40}$ Yang dimaksud "rehabilitasi medis" adalah sebuah proses kegiatan pengobatan secara terpadu bertujuan untuk memulihkan kondisi fisik Anak, Anak sebagai Korban, dan/atau Anak sebagai Saksi. Yang dimaksud "rehabilitasi sosial" adalah sebuah proses kegiatan pemulihan secara terpadu, baik fisik, mental maupun juga sosial, agar Anak, Anak sebagai Korban, dan/atau Anak sebagai Saksi dapat kembali melaksanakan fungsi sosial dalam kehidupan di dalam masyarakat. Yang dimaksud "reintegrasi sosial" adalah sebuah proses penyiapan Anak, Anak sebagai Korban, dan/atau Anak sebagai Saksi untuk dapat kembali ke dalam lingkungan keluarga dan lingkungan masyarakat. ${ }^{41}$

Apabila Anak sebagai Korban memerlukan tindakan pertolongan dengan segera, Penyidik, tanpa laporan sosial yang berasal dari Pekerja Sosial Profesional, dapat langsung merujuk Anak sebagai Korban ke rumah sakit atau lembaga yang menangani yang berkaitan dengan pelindungan anak sesuai dengan kondisi Anak sebagai Korban. ${ }^{42}$ Yang dimaksud "memerlukan tindakan pertolongan segera" adalah sebuah kondisi anak yang mengalami penderitaan, baik fisik maupun psikis, hingga harus segera diatasi. ${ }^{43}$

Anak sebagai Korban dan/atau Anak sebagai Saksi yang memerlukan pelindungan

38 Pasal 60 ayat (2) UU No. 11 Tahun 2012 tentang SPPA. 39 Pasal 90 ayat (1) UU No. 11 Tahun 2012 tentang SPPA. 40 Pasal 91 ayat (3) UU No. 11 Tahun 2012 tentang SPPA. 41 Penjelasan Pasal 91 ayat (3) UU No. 11 Tahun 2012 tentang SPPA.

42 Pasal 91 ayat (2) UU No. 11 Tahun 2012 tentang SPPA.

43 Penjelasan Pasal 91 ayat (2) UU No. 11 Tahun 2012 tentang SPPA.

44 Pasal 91 ayat (4) UU No. 11 Tahun 2012 tentang SPPA.

45 Pasal 58 ayat (1) UU No. 11 Tahun 2012 tentang SPPA. 
untuk mendapatkan perlindungan dari lembaga yang menangani tentang pelindungan saksi dan korban atau rumah perlindungan sosial sesuai dengan ketentuan pada peraturan perundang-undangan. ${ }^{44}$ Pada saat memeriksa Anak sebagai Korban dan/atau Anak sebagai Saksi, Hakim dapat memerintahkan untuk Anak dibawa keluar ruang sidang. ${ }^{45}$ Anak sebagai Korban dan/atau Anak sebagai Saksi berhak atas semua pelindungan dan juga hak-hak yang diatur pada ketentuan peraturan perundang-undangan. ${ }^{46}$

Pada dasarnya, korban mempunyai posisi sentral di dalam sistem peradilan pidana. ${ }^{47}$ Oleh karena itu korban harus sangat diperhatikan dengan baik. Hak-hak diberikan dalam UU No. 11 Tahun 2012 mengenai SPPA sangatlah penting. Mengingat posisi korban sebagai peran yang sangat penting untuk dapat membongkar kejahatan dan dengan adanya proses diversi, korban dapat mengetahui mengapa dirinya menjadi korban dari suatu tindak pidana dan korban dapat meminta kepada pelaku ganti rugi yang harus diberikan untuk mengembalikan keadaan seperti semula, keadaan sebelum terjadi suatu tindak pidana yang menimpa korban. Hal tersebut dikenal dengan bentuk keadilan restiratif. Seperti disampaikan oleh Tony Mashall sebagaimana telah dikutip dalam bab
II, bahwa konsep restorative menitikberatkan pada keadilan yang dapat memulihkan. ${ }^{48}$ Konsep ini telah diakomodir oleh UU SPPA terkait dengan perlindungan Anak Korban sebagaimana dicantumkan dalam Pasal 90 dan Pasal 91 UU SPPA.

Namun demikian, lebih spesifik lagi yang berkaitan dengan pengaturan perlindungan anak, Indonesia juga memiliki UU No. 23 Tahun 2002 mengenai Perlindungan Anak. UU ini juga mengatur yang berkaitan dengan jenis-jenis anak sebagai korban dalam suatu tindak pidana yaitu: anak yang menjadi korban penyalahgunaan narkotika, alkohol, psikotropika, dan juga zat adiktif lainnya (napza), anak sebagai korban penculikan, penjualan, perdagangan, anak sebagai korban kekerasan baikfisik dan/ataumental, anakyang menyandang cacat, dan anak sebagai korban dari perlakuan salah dan penelantaran ${ }^{49}$, anak sebagai korban dari kerusuhan, anak sebagai korban dari bencana alam, ${ }^{50}$ dan anak sebagai korban dari tindak pidana. ${ }^{51}$

Undang-undang Perlindungan Anak Nomor 23 Tahun 2002 mengenai Perlindungan Anak dalam pelaksanaannya mempunyai banyak kekurangan antara lain:

1. belum adanya penjelasan tentang pengertian kekerasan, padahal hal ini sangat penting untuk dijabarkan, hal-hal

46 Pasal 89 UU No. 11 Tahun 2012 tentang SPPA.

47 Lilik Mulyadi, Kompilasi Hukum Pidana dalam Perspektif Teori dan Praktik, (Bandung: Mandar Maju, 2007), hlm. 165 .

48 Zehr, H \& Mika, H, "Fundamental concepts of Restorative Justice”, Contemporary Justice Review 1, (1998): 47-55.

49 Pasal 1 ayat (15) UU No 23 Tahun 2002 tentang Perlindungan Anak.

50 Pasal 60 UU No 23 Tahun 2002 tentang Perlindungan Anak.

51 Pasal 64 ayat (1) UU No 23 Tahun 2002 tentang Perlindungan Anak. 
apa saja yang digolongkan sebagai tindakan kekerasan pada anak.

2. dalam lingkungan sekolah, anak belum mendapat perlindungan dari kekerasan yang dilakukan oleh tenaga pengajar di sekolah atau teman-teman sekolah,

3. dalam hal anak yang dipisahkan dari kedua orang tuannya demi kepentingan terbaik sang anak, UU ini tidak memberi penjelasan sejauh mana peran orang tua selama pembinaan dilaksanakan.

4. orang tua wali tidak disebutkan dalam usaha untuk perlindungan pada anak, jadi apabila anak diasuh walinya dapat dikatakan bahwa wali tidak memiliki kewajiban untuk memberikan perlindungan pada anak

5. belum adanya perlindungan pada anak sebagai korban kejahatan seksual

6. belum adanya sebuah upaya restitusi dari pelaku kepada korban, misalnya pada korban kejahatan seksual

Maraknya tindak pidana yang melibatkan anak menjadi korban kejahatan seksual baik yang dilakukan oleh orang tuanya sendiri, dilakukan temannya, maupun dilakukan oleh orang yang tidak dikenal maka mendorong pemerintah segera melakukan perubahan dengan mengesahkan UU No. 35 Tahun 2014 mengenai Perubahan atas UU No. 23 Tahun 2003 mengenai Perlindungan Anak. Di dalamnya terdapat beberapa sanksi untuk atau sebagai pemberatan bagi pelaku kejahatan seksual. Sanksi pemberatan bagi pelaku kejahatan seksual yang telah diatur di dalam Undang-undang No. 35 tahun 2014 adalah sebagai berikut:

1. Setiap Orang dilarang untuk melakukan Kekerasan atau ancaman Kekerasan dengan cara memaksa Anak melakukan persetubuhan dengannya atau juga dengan orang lain. Bagi Setiap orang yang melanggar hal tersebut, dipidana dengan pidana penjara paling singkat selama 5 (lima) tahun dan paling lama selama 15 (lima belas) tahun dan juga denda paling banyak Rp. 5.000.000.000,00 (lima miliar rupiah) ${ }^{52}$

Apabila tindak pidana tersebut dilakukan dilakukan oleh Orang Tua, Wali, pengasuh Anak, pendidik, atau tenaga kependidikan, maka pidananya ditambah $1 / 3$ (sepertiga) dari ancaman pidana $\operatorname{diatas}^{53}$

2. Setiap Orang dilarang untuk melakukan Kekerasan atau ancaman Kekerasan, dengan cara memaksa, melakukan tipu muslihat, melakukan serangkaian kebohongan, atau membujuk Anak untuk melakukan atau juga membiarkan dilakukan perbuatan cabul. Bagi Setiap orang yang melanggar hal tersebut, dipidana dengan pidana penjara paling singkat selama 5 (lima) tahun dan paling lama selama 15 (lima belas) tahun dan denda paling banyak Rp. 5.000.000.000,00 (lima miliar rupiah). ${ }^{54}$ Apabila suatu tindak pidana tersebut dilakukan oleh Orang Tua, oleh Wali, oleh pengasuh Anak, oleh pendidik, atau oleh tenaga kependidikan, maka pidananya ditambah menjadi 
1/3 (sepertiga) dari ancaman pidana sebagaimana yang telah disebutkan diatas. ${ }^{55}$

3. Setiap Orang dilarang untuk menempatkan, membiarkan, melakukan, menyuruh untuk melakukan, atau turut serta melakukan suatu eksploitasi secara ekonomi dan/atau seksual pada Anak. Bagi Setiap orang yang melanggar hal tersebut.

Untuk terlaksananya perlindungan pada anak dengan maksimal, maka perlu adanya koordinasi kerjasama antara pemerintah, masyarakat dan juga orang tua. ${ }^{56}$ Perlindungan terhadap anak merupakan kewabijan bersama, namun apabila yang seharusnya melindungi anak malah justru akan melakukan tindak pidana pada anak, maka sudah seharusnya mendapatkan hukuman yang lebih.

Gary Becker mengemukakan beberapa pendapatnya terkaitdengan rasionalitas dengan hukum pidana. Pertama, kebijakan hukum pidana yang optimal (the optimal criminal justice policy). Pemikiran ini berkaitan dengan analisis ongkos dan keuntungan (cost and benefit analysis), yang mengandung arti suatu usaha untuk mendapatkan alokasi optimal sumberdaya dalam masyarakat di dalam memerangi kejahatan. Asumsi teori yang digabung adalah jika sanksi pidana yang ada cukup berat, setiap penjahat pasti akan menghindar dari kemungkinan ditangkap, dalam hal ini akan mengurangi kejahatan. ${ }^{57}$

Kedua, keputusan individu dalam kaitannya dengan aktivitas criminal (the individual's decision about criminal activity). Penjahat adalah seorang pelaku rasional yang menimbang antara ongkos dan keuntungan, serta waktu dan sumber daya yang dialokasikan di antara aktivitas penjahat, sehingga diketahui mana yang dapat mendatangkan keuntungan yang paling besar. ${ }^{58}$ Semua orang (tidak hanya pelaku kejahatan) adalah pelaku rasional yang berdasarkan subjektivitasnya menimbang ongkos dan keuntungan dari kegiatan yang dilakukannya. Beberapa orang memilih kegiatan yang dilabeli penjahat karena bagi mereka untuk jumlah keuntungan yang diperoleh dari kegiatan tersebut melebihi ongkos yang harus dikeluarkan. Untuk mencegah mereka dari perbuatan pidananya, yang dilakukan adalah dengan meningkatkan ongkos yang dikeluarkan, sehingga dengan demikian keuntungan yang diperoleh lebih kecil. Caranya adalah dengan meningkatkan sanksi pidana yang akan djatuhkan.

Seperti yang disampaikan oleh Gery Becker bahwa manusia itu mahluk yang rasional, jadi apabila sanksi yang di jatuhkan lebih besar dari pada hasil yang di peroleh, penjahat atau calon penjahat akan menghindari tindak pidana tersebut. Upaya pemerintah

56 Maidin gultom, Perlindungan Hukum Terhadap Anak dalam Sistem Peradilan Pidana Anak di Indonesia, (Bandung: Rafika Aditama, 2006), hlm. 35.

57 William L Barnes Jr, "Revenge on Utilitarianism: Renaouncing A Comprehensive economics Theory of Crime and Phunisment", Indiana law journal, Vol. 74, No 627, (1999), dalam Mahrus Ali, Asas, Teori dan Praktek Hukum Pidana Korupsi, (Yogyakarta: UII Press, 2013), hlm. 246.

58 D M. Khan, "Social Influence, Social Meaning, and Deterrence", Virginia Law Review, No. 83, dalam Mahrus Ali, Asas, Teori dan Praktek Hukum Pidana Korupsi, (Yogyakarta: UII Press, 2013), hlm. 246. 
untuk melindungi anak dari kajahatan seksual, apabila dilihat dari pendapat Gerry Becker, sudah merupakan tindakkan yang tepat.

Terhadap Anak yang menjadi korban tindak pidana, bagi Pemerintah, baik Pemerintah Daerah, dan juga lembaga negara lainnya berkewajiban dan juga bertanggung jawab untuk memberikan sebuah Perlindungan Khusus. ${ }^{59}$ Dengan kata lain, Anak yang menjadi korban suatu tindak pidana mempunyai hak-hak yang telah diatur di dalam Undang-undang No. 35 Tahun 2014 yaitu sebuah hak untuk memperoleh perlindungan khusus. Perlindungan Khusus tersebut akan diberikan kepada: Anak sebagai korban dari tindak pidana penculikan, penjualan, dan/atau perdagangan; Anak sebagai korban Kekerasan fisik dan/atau psikis; Anak sebagai korban kejahatan seksual; Anak sebagai korban jaringan terorisme; Anak sebagai korban dari perlakuan salah dan juga penelantaran; dan Anak yang menjadi korban stigmatisasi dari pelabelan yang terkait dengan kondisi Orang Tuanya. ${ }^{60}$ Yang dimaksud dengan perlindungan khusus adalah merupakan suatu bentuk perlindungan yang dapat diterima oleh Anak dalam situasi dan kondisi tertentu seorang anak untuk mendapatkan jaminan sebuah rasa aman terhadap ancaman yang dapat membahayakan dirinya dan jiwanya dalam tumbuh kembangnya. ${ }^{61}$

Bentuk perlindungan khusus yang dapat diberikan pada anak yang menjadi korban suatu tindak pidana dilakukan melalui penanganan yang cepat, termasuk pengobatan dan/atau rehabilitasi secara fisik, psikis, dan sosial, serta pencegahan penyakit dan gangguan kesehatan lainnya; pendampingan dari psikososial pada saat pengobatan sampai dengan saat pemulihan; pemberian sebuah bantuan sosial bagi Anak yang mana berasal dari Keluarga tidak mampu; dan pemberian sebuah perlindungan dan juga pendampingan pada setiap proses peradilan berjalan. ${ }^{62}$

Bentuk-bentuk dari Perlindungan Khusus bagi anak yang menjadi korban suatu tindak pidana akan diurai lebih spesifik lagi, berikut uraiannya:

Perlindungan Khusus bagi Anak korban dari tindak pidana kejahatan seksual dilakukan melalui upaya: ${ }^{63}$

1. edukasi mengenai kesehatan reproduksi, nilai-nilai agama, dan juga nilai-nilai kesusilaan;

59 Pasal 59 ayat (1) UU No. 35 Tahun 2014 tentang Perubahan atas UU 23/2002.

60 Pasal 59 ayat (2) UU No. 35 Tahun 2014 tentang Perubahan atas UU 23/2002 Perlindungan Khusus kepada Anak sebagaimana dimaksud pada ayat (1) diberikan kepada: a. Anak dalam situasi darurat; b. Anak yang berhadapan dengan hukum; c. Anak dari kelompok minoritas dan terisolasi; d. Anak yang dieksploitasi secara ekonomi dan/atau seksual; e. Anak yang menjadi korban penyalahgunaan narkotika, alkohol, psikotropika, dan zat adiktif lainnya; f. Anak yang menjadi korban pornografi; g. Anak dengan HIV/AIDS; h. Anak korban penculikan, penjualan, dan/atau perdagangan; i. Anak korban Kekerasan fisik dan/atau psikis; j. Anak korban kejahatan seksual; k. Anak korban jaringan terorisme; 1. Anak Penyandang Disabilitas; m. Anak korban perlakuan salah dan penelantaran; n. Anak dengan perilaku sosial menyimpang; dan o. Anak yang menjadi korban stigmatisasi dari pelabelan terkait dengan kondisi Orang Tuanya

61 Pasal 1 angka 15 UU No. 35 Tahun 2014 tentang Perubahan atas UU 23/2002.

62 Pasal 59A UU No. 35 Tahun 2014 tentang Perubahan atas UU 23/2002.

63 Pasal 69A UU No. 35 Tahun 2014 tentang Perubahan atas UU 23/2002. 
2. rehabilitasi social pada anak;

3. pendampingan psikososial pada saat pengobatan sampai dengan saat pemulihan; dan juga

4. pemberian sebuah perlindungan dan juga pendampingan pada setiap tingkat pemeriksaan mulai dari proses penyidikan, proses penuntutan, sampai dengan proses pemeriksaan di sidang pengadilan.

Perlindungan Khusus bagi Anak yang menjadi korban atau dieksploitasi secara ekonomi dan/atau seksual dilakukan melalui: ${ }^{64}$

a. penyebarluasan dan/atau sosialisasi pada ketentuan peraturan perundang-undangan yang berkaitan

b. dengan Perlindungan Anak yang menjadi korban atau dieksploitasi secara ekonomi dan/atau seksual;

c. pemantauan, pelaporan, dan pemberian sanksi pada pelaku; dan

d. perlibatan berbagai perusahaan, perlibatan serikat pekerja, perlibatan lembaga swadaya masyarakat, dan juga perlibatan Masyarakat dalam penghapusan eksploitasi pada Anak secara ekonomi dan/atau seksual.

Perlindungan khusus bagi Anak yang menjadi korban dari penyalahgunaan narkotika, alkohol, psikotropika, dan juga penyalahgunaan zat adiktif lainnya. ${ }^{65}$ Anak yang terlibat dalam produksi dan juga distribusinya dilakukan melalui upaya pengawasan, pencegahan, perawatan, dan juga melalui upaya rehabilitasi.

Perlindungan Khusus bagi Anak yang menjadi korban tindak pidana pornografi dilaksanakan melalui upaya pembinaan, pendampingan, serta upaya pemulihan sosial, kesehatan fisik dan juga mental. ${ }^{66}$

Perlindungan Khusus bagi Anak yang menjadi korban tindak pidana penculikan, penjualan, dan/atau perdagangan ${ }^{67}$ dilakukan melalui upaya pengawasan, perlindungan, pencegahan, perawatan, dan juga upaya rehabilitasi.

Perlindungan Khusus bagi Anak yang menjadi korban tindak pidana Kekerasan fisik dan/atau psikis dilakukan melalui upaya: ${ }^{68}$

a. penyebarluasan dan juga sosialisasi pada ketentuan peraturan perundang-undangan yang melindungi

b. Anak sebagai korban tindak pidana Kekerasan; dan

c. pemantauan, pelaporan, dan juga pemberian sanksi.

Perlindungan Khusus bagi Anak yang menjadi korban tindak pidana jaringan terorisme dilakukan melalui upaya: ${ }^{69}$

a. edukasi mengenai pendidikan, ideologi, dan nilai-nilai nasionalisme; 
b. konseling mengenai bahaya terorisme;

c. rehabilitasi sosial; dan juga

d. pendampingan social pada anak sebagai korban.

Perlindungan Khusus bagi Anak yang menjadi korban dari perlakuan yang salah dan penelantaran dilakukan dengan upaya ${ }^{70}$ pengawasan, upaya pencegahan, upaya perawatan, upaya konseling, upaya rehabilitasi sosial, dan juga upaya pendampingan sosial.

Perlindungan khusus bagi Anak yang menjadi korban dari stigmatisasi pelabelan yang berkaitan dengan kondisi orang tuanya dilakukan melalui: ${ }^{71}$ bimbingan konseling, melalui rehabilitasi sosial, dan juga melalui pendampingan sosial.

Selain hak perlindungan khusus yang diberikan kepada anak yang menjadi korban suatu tindak pidana yang disebutkan diatas, anak yang menjadi korban tindak pidana juga mempunyai hak-hak untuk mengajukan ke pengadilan berupa hak-hak atas restitusi yang menjadi tanggung jawab pelaku kejahatan. Namun tidak semua anak yang menjadi korban suatu tindak pidana memiliki hak tersebut, yang memiliki hak untuk mengajukan restitusi ke pengadilan ialah: ${ }^{72}$

a. Anak sebagai korban yang dieksploitasi secara ekonomi dan/atau seksual;

b. Anak sebagai korban tindak pidana pornografi; c. Anak sebagai korban tindak pidana penculikan, penjualan, dan/atau perdagangan;

d. Anak sebagai korban tindak pidana Kekerasan fisik dan/atau psikis;

e. Anak sebagai korban tindak pidana kejahatan seksual.

Melindungi anak pada hakikatnya adalah melindungi keluarga, melindungi masyarakat, dan juga melindungi bangsa. ${ }^{73}$ Oleh karena itu perlindungan pada anak sangatlah penting. Termasuk perlindungan pada Anak sebagai korban kejahatan. Oleh karena itu hak-hak anak diatas menjadi sangatlah penting untuk dilindungi, terutama bagi anak korban kejahatan seksual. Dihukumnya seorang pelaku kejahatan seksual tidak menghilangkan rasa-rasa traumatis yang diderita korban. ${ }^{74}$ Oleh karena itu adanya hak korban untuk meminta restitusi kepada korban menjadi poin penting. Karena hak restitusi ini yang digunakan untuk memulihkan trauma yang diderita oleh anak korban kejahatan seksual.

Jaminan perlindungan jangka panjang ini tentunya diberikan dari Undang-Undang karena pertimbangan tingkatancamanterhadap saksi dan korban dalam mengungkap suatu tindak pidana itu pun dapat berdampak jangka panjang. Adapun lembaga yang mempunyai tugas dan berwenang memberikan identitas baru bagi korban adalah LPSK (Lembaga Perlindungan Saksi dan Korban). Sesuai

71 Pasal 71B UU No. 35 Tahun 2014 tentang Perubahan atas UU 23/2002.

72 Pasal 71D ayat (1) UU No. 35 Tahun 2014 tentang Perubahan atas UU 23/2002.

73 J.E. Sahetapy dkk, Bunga Rampai Viktimisasi, (Bandung: PT. Eresco, 1995), hlm. 135.

74 Rena Yulia, Viktimologi perlindungan hukum terhadap korban kejahatan, (Yogyakarta: Graha Ilmu, 2010), hlm. 14. 
ketentuan Pasal 1 angka 3 UU PSK, LPSK adalah lembaga yang bertugas dan berwenang untuk memberikan perlindungan dan hak-hak lain kepada Saksi dan/atau Korban.

Berdasarkan uraian di atas, UU No. 35 Tahun 2014 secara spesifik memberikan perlindungan pada anak sebagai korban kejahatan seksual. Bentuk perlindungan yang diberikan kepada anak sebagai korban kejahatan seksual sebagaimana telah dikutip sebelumnya diatur dalam Pasal 69 A UU No.

\section{Tahun 2014 berupa:}

1. edukasi mengenai kesehatan reproduksi, nilai-nilai agama, dan nilai kesusilaan;

2. rehabilitasi social pada korban;

3. pendampingan psikososial pada saat pengobatan sampai dengan pemulihan; dan

4. Pemberian sebuah perlindungan dan juga pendampingan pada setiap tingkat pemeriksaan mulai dari tingkat penyidikan, tingkat penuntutan, sampai dengan tingkat pemeriksaan di sidang pengadilan.

Dari beberapa peraturan yang mengatur mengenai anak dan anak korban kejahatan seksual seperti UU No. 11 Tahun 2012 mengenai SPPA, UU No. 31 Tahun 2014 mengenai Perlindungan Saksi dan perlindungan Korban dan UU No, 35 Tahun 2014 mengenai perlindungan anak, dan dapat dibuat suatu perbandingan dalam Tabel 1.

Berdasarkan Tabel 1. diatas dapat dilihat hak-hak yang diberikan dan dilindungi oleh Negara melaui UU No. 31 Tahun 2014, melalui UU No. 11 Tahun 2012 dan melaui UU No. 35 Tahun 2014, cukup banyak. Pada UU No. 31 Tahun 2014 mengatur tentang hak-hak korban secara umum tanpa memandang apakah korban adalah anak atau orag dewasa. Sementara UU No. 11 Tahun 2012 mulai memberikan perlindungan bagi Anak Korban Tindak pidana secara umum, namun tidak spesifik pada jenis tindak pidananya. Lebih lanjut, UU No. 35 Tahun 2014 sudah mengatur dengan spesifik membedakan hak-hak anak korban tindak pidana tertentu. Dibandingkan dengan UU lainnya, terlihat bahwa UU No. 35 Tahun 2014 lebih akomodatif dalam memberikan perlindungan anak sebagai korban tindak pidana kejahatan seksual.

UU No. 35 Tahun 2014 mengenai Perlindungan Anak cukup banyak memberikan perlindungan pada anak, bahkan sebelum kejahatan terjadi pada anak, UU No. 35 Tahun 2014 yang mengatur Perlindungan Anak telah memberi perlindungan terhadap untuk tidak menjadi korban dari suatu tindak pidana. Misalnya pada tindak pidana kejahatan seksual dilakukan dengan upaya edukasi mengenai kesehatan reproduksi, nilai-nilai agama, dan juga nilai-nilai kesusilaan. Hal dilakukan agar anak-anak dapat lebih memahami tentang alat reproduksi mereka, jadi mereka dapat menghindar apabila ada tanda-tanda orang yang ingin melakukan sesuatu yang tidak wajar pada alat reproduksi mereka. Kemudian ditanamkan nilai agama dan kesopanan, ini yang merupakan pedoman hidup bagi manusia. Agama tentu akan melindungi setiap 


\section{Tabel 1. Perbandingan Perlindungan Anak Korban Kekerasan Seksual dalam UU} No. 31 Tahun 2014, UU No. 11 Tahun 2012 dan UU No. 35 Tahun 2014

\begin{tabular}{|c|c|c|c|}
\hline & $\begin{array}{c}\text { UU No. } 31 \text { Tahun } 2014 \text { Tentang } \\
\text { Perubahan atas UU 13/2006 } \\
\text { tentang Perlindungan Saksi dan } \\
\text { Korban }\end{array}$ & $\begin{array}{l}\text { UU No. } 11 \text { Tahun } \\
2012 \text { Tentang Sistem } \\
\text { Peradilan Pidana } \\
\text { Anak }\end{array}$ & $\begin{array}{c}\text { UU No. } 35 \text { Tahun } 2014 \text { Tentang Perubahan } \\
\text { atas UU No. } 23 \text { Tahun } 2002 \text { tentang } \\
\text { Perlindungan Anak }\end{array}$ \\
\hline $\begin{array}{l}\text { Hak-Hak } \\
\text { Yang } \\
\text { Diberikan } \\
\text { dan } \\
\text { Dilindungi }\end{array}$ & 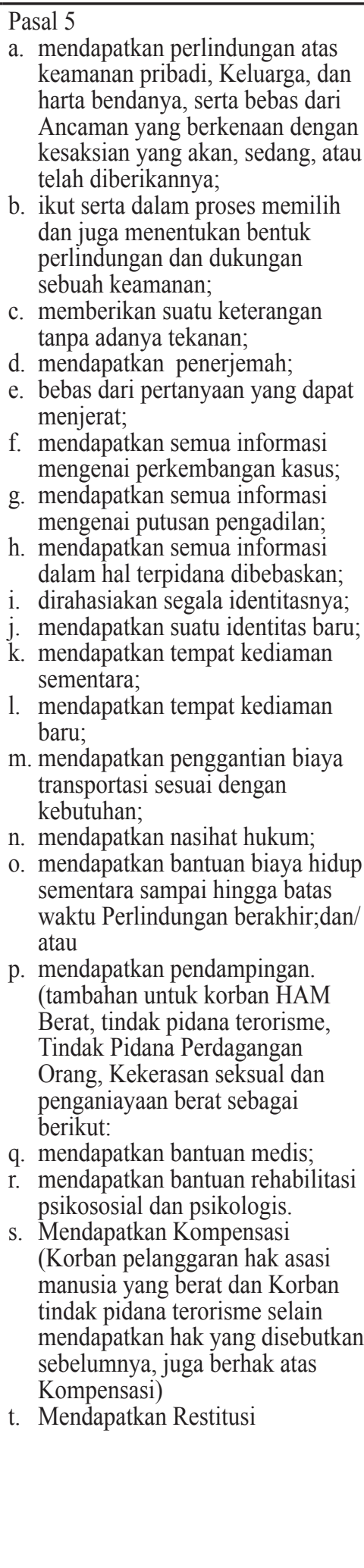 & $\begin{array}{l}\text { Pasal 9,60,61,89, } 90,97 \\
\text { a. tidak dipublikasikan } \\
\text { identitasnya; } \\
\text { b. memperoleh } \\
\text { pendampingan orang } \\
\text { tua/Wali dan orang } \\
\text { yang dipercaya oleh } \\
\text { Anak; } \\
\text { c. memperoleh } \\
\text { pelayananan } \\
\text { kesehatan; dan } \\
\text { d. memperoleh hak } \\
\text { lain sesuai dengan } \\
\text { ketentuan peraturan } \\
\text { perundang- } \\
\text { undangan. } \\
\text { e. Hak untuk ikut serta } \\
\text { dalam proses diversi } \\
\text { f. Dalam hal tertentu } \\
\text { Anak Korban } \\
\text { diberi kesempatan } \\
\text { oleh Hakim untuk } \\
\text { menyampaikan } \\
\text { pendapat tentang } \\
\text { perkara yang } \\
\text { bersangkutan. } \\
\text { g. upaya rehabilitasi } \\
\text { medis dan } \\
\text { rehabilitasi sosial, } \\
\text { baik di dalam } \\
\text { lembaga maupun di } \\
\text { luar lembaga; } \\
\text { rumah perlindungan } \\
\text { sosial } \\
\text { h. jaminan keselamatan, } \\
\text { baik fisik, mental, } \\
\text { maupun sosial; } \\
\text { i. kemudahan dalam } \\
\text { mendapatkan } \\
\text { informasi mengenai } \\
\text { perkembangan } \\
\text { perkara. } \\
\text { j. reintegrasi sosial dari } \\
\text { lembaga atau instansi } \\
\text { yang menangani } \\
\text { pelindungan anak } \\
\text { k. memperoleh } \\
\text { pelindungan } \\
\text { dari lembaga } \\
\text { yang menangani } \\
\\
\end{array}$ & 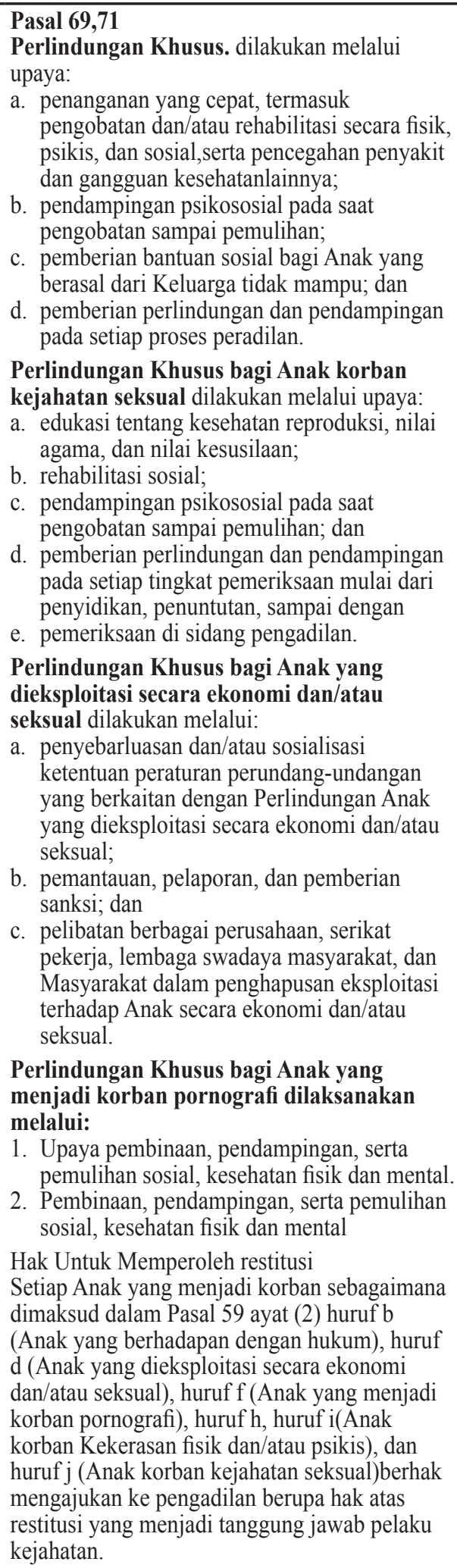 \\
\hline
\end{tabular}


umat manusia yang mengikuti petunjuk yang diajarkan melalui kitab-kitabnya (dalam Islam misalnya seperti Al-Quran, atau pada umat Kristiani seperti Kitab Injil). Misalnya seperti agama Islam yang melarang dua orang yang berlainan jenis kelamin untuk duduk, ataupun berjalan-jalan berdua saja. Karena ditakutkan akan godaan yang dapat ditumbul yang kemudian dapat memicu terjadinya hubungan seks. Apabila anak-anak mengetahui akan hal ini dan kemudian mengamalkannya, mereka dapat menghindar dari ajakan teman atau family untuk berada berdua saja berjalanberjalan atau melakukan aktifitas lainnya. Karena kejahatan seksual sering terjadi yang pelakunya merupakan kelurga, teman atau kerabat korban itu sendiri.

Namun, apabila dilihat di dalam UU No. 35 Tahun 2014 yaitu khusus pada aturan yang mengatur terkait restitusi, terlihat bahwa rumusan tentang aturan tersebut kurang mencerminkan sebuah restorative justice. Dari rumusannya, disebutkan di dalam Pasal 71D UU No. 35 Tahun 2014 yaitu bahwa korban berhak mengajukan ke pengadilan berupa hak-hak atas restitusi yang telah menjadi tanggung jawab pelaku kejahatan. Kemudian dijelaskan bahwa suatu pembayaran ganti kerugian yang dibebankan kepada pelaku berdasarkan putusan pengadilan yang berkekuatan hukum tetap atas kerugian materiil dan/atau imateriil yang diderita korban atau ahli warisnya. Hal ini berbeda dengan UU No. 11 Tahun 2012 yang secara tegas pada Pasal 5 UU SPPA dikatakan bahwa sistem peradilan pidana anak wajib mengutamakan menggunakan pendekatan keadilan restoratif.

Menuntut kerugian materil dan imateriil sebagai salah satu bentuk restitusi dalam UU No. 35 Tahun 2015 akan sangat sulit untuk dilakukan dalam praktek. Karena kerugian imateriil sangat sulit mencari tolak ukurnya. Pada posisi seperti ini yang nampak hanyalah pembalasan. Sebagaimana yang menjadi ciri dari retributive justice bahwa tujuan pidana adalah semata-mata untuk pembalasan. ${ }^{75}$

Herbert L. Packer menyebutkan beberapa hal sebagai betikut. ${ }^{76}$

1. Sanksi pidana sangat diperlukan, kita tidak dapat hidup dalam masa sekarang maupun dimasa yang datang tanpa pidana (the criminal sanction is indispensable, we could not, now or in the foresecable future, get along without it).

2. Sanksi pidana adalah alat atau sarana terbaik yang telah tersedia, yang kita miliki untuk menghadapi ancamanancaman dari bahaya (the criminal sanction is best available device are have for dealing with gross and immediate harm and threats of harm).

3. Sanksi pidana suatu ketika adalah “penjamin yang utama/terbaik" dari 
kebebasan manusia. Ia adalah penjamin apabila digunakan secara cermat dan manusiawi, ia merupakan pengaancaman apabila digunakan secara sembarangan dan juga secara paksa (the criminal sanction is at once prime guarantor, used indiscriminately and coercively, it is threatener).

Seperti yang dikatakan oleh Harbert L. Packer diatas bahwa, sanksi pidana adalah penjamin terbaik apabila digunakan dengan secara cermat dan manusiawi, akan tetapi akan menjadi ancaman apabila digunakan secara paksa dan sembarangan. Sama seperti hak restitusi pada korban kejahatan seksual yang diatur pada Pasal 71D UU No. 35 Tahun 2014, hak-hak tersebut sangat dibutuhkan oleh korban tetapi sebuah bentuk dari restitusi adalah hal penting yang harus diperhatikan.

Restitusi yang telah diatur pada Pasal 71D UU No. 35 Tahun 2014 terlihat hanya untuk memuaskan keinginan dari masyarakat untuk menghukum pelaku sebarat-beratnya atas perbuatannya. Masyarakat merasa bahwa mereka juga ikut mengalami dampak dari perbuatan pelaku tersebut. Akan tetapi korbanlah yang merupakan orang yang paling merasakan dampak dari tindak pidana yang menimpa dirinya. Seharusnya yang menjadi focus perhatian ialah korban. Sebagaimana yang dideskripsikan oleh Israel Drapkin dan Emilo Viano: ${ }^{77}$

"Although we are accutomed to say that act affect all of society, we cannot deny that the actual victim suffers much more though personal losses than society. In the face incurable, undiputed report, we also forced to acknowledge that the victim is most often an individual physically or financially unable to revover from the criminal (kendati pun kita bisa mengatakan bahwa suatu tindak pidana mempengaruhi semua masyarakat, kita tidak dapat menyangkal bahwa korban yang secara individual jauh menderita dari pada kerugian dalam masyarakat. Dalam kenyataan pula diakui bahwa korban yang secara individu, fisik maupun financial sering tidak mampu mengatasi tindak pidana)"

Anak sebagai korban tindak pidana kejahatan seksual sejatinya tidak akan merasa puas dengan tuntutan nilai ganti rugi (restitusi) yang tinggi, yang mereka butuhkan ialah bagaimana dapat mengembalikan kondisi fisik maupun kejiwaannya seperti dahulu kala. Hal ini yang seharusnya ada sebagai bentuk dari restitusi dimana kewajiban melakukan restitusi materiil dan immaterial korban harusnya tidak hanya merupakan tanggung jawab Negara, tetapi juga menjadi tanggung jawab pelalu mengadakan pemulihan terhadap keadaan korban. Sehingga konsep restorative justice penting ditegaskan dalam UU No. 35 Tahun 2014.

Merumuskan bentuk dari restitusi juga secara tidak langsung akan menjelaskan kepada pelaku bahwa memberikan restitusi

77 Israel Drapkin dan Emilo Viano, Victimologi: A new Focus, (Massachusetts: London: Lexington Books, D.C. Health and Company, 1974), p. 141 dalam Lilik Mulyadi, Kompolasi Hukum Pidana Dalam Perspektif Teoritik dan Praktik Pengadilan, (Bandung: Bandar Maju, 2007), hlm. 17. 
merupakan salah satu sanksi yang harus dia terima, dan yang lebih penting lagi bahwa korban harus menjalani berbagai proses pemulihan untuk dapat kembali hidup normal. Hal ini diharapakan akan menyadarkan pelaku atas perbuatannya. Jadi pelaku diharapkan menyadari dan menyesali kesalahan yang dilakukan semata-mata bukan karena beratnya sanksi yang harus diterima, akan tetapi juga karena melihat begitu sulit dan membutuhkan proses yang panjang untuk memulihkan keadaan korban.

Jadi, sangat penting untuk merinci hal-hal yang harus dilakukan oleh pelaku terhadap korban sebagai bentuk restitusi, hal ini juga sesuai dengan prinsip dari restorative justice, yakni mengembalikan keadaan yang telah dirusak oleh pelaku ke keadaan semula seperti sebelum terjadinya kejahatan tersebut dan juga sebagai bentuk penyadaran terhadap pelaku kejahatan seksual. Meski sangat sulit untuk dapat mengembalikan keadaan semula terhadap korban kejahatan seksual, namun dengan perawatan medis dan atau psikologis diharapkan dapat membantu korban untuk

\section{DAFTAR PUSTAKA}

\section{Buku}

Ali, Mahrus. Asas, Teori dan Praktek Hukum

Pidana Korupsi. Yogyakarta: UII Press, 2013.

Arif, Barda Nawawi. Bunga Rampai Kebijakan Hukum Pidana. Jakarta: Kencana, 2008.

- Kebijakan Legislatif

Dalam Penanggulangan kejahtan

Dengan Pidana Penjara. Semarang:

Universitas Diponegoro, 1996.

Bentham, Jeremy. Teori Perundang- dapat hidup normal kembali.

\section{Simpulan}

UU No. 31 Tahun 2014 mengatur hak korban secara umum tanpa memandang apakah korban adalah anak atau orag dewasa. Sementara UU No. 11 Tahun 2012 mulai memberikan perlindungan pada Anak sebagai Korban Tindak pidana secara umum, namun tidak spesifik pada jenis-jenis tindak pidananya. Lebih lanjut, UUNo. 35 Tahun 2014 telah mengatur secara spesifik membedakan hak-hak anak sebagai korban tindak pidana tertentu. Dibandingkan dengan UU lainnya, terlihat bahwa UU 35/2014 lebih akomodatif dalam memberikan suatu perlindungan anak korban kejahatan seksual. Namun, dalam pengaturan perlindungan anak sebagai korban kekerasan seksual dalam Pasal 71D UU 35/2014 mengenai perubahan terhadap UU 23/2002 belum sepenuhnya mencerminkan penanganan dengan pendekatan keadilan restoratif.

Undangan Prinsip-Prinsip Legislasi, Hukum Perdata dan Hukum Pidana. Bandung: Penerbit Nusamedia \& Penerbit Nuansa, 2006.

Djamil, M. Nasir. AnakBukan UntukDihukum. Jakarta: Sinar Grafika, 2013.

Drapkin, Israel dan Emilo Viano. Victimologi: A new Focus. Massachusetts, London: Lexington Books, D.C. Health and Company, 1974.

Gultom, Maidin. Perlindungan Hukum 
Terhadap Anak dalam Sistem Peradilan

Pidana Anak di Indonesia. Bandung:

Rafika Aditama, 2006.

Hamzah, Andi. Perlindungan Hak-Hak Asasi

Manusia dalam Kitab Undang-Undang

Hukum Acara Pidana. Bandung:

Binacipta, 1986.

Hartono, Sunaryati. Penelitian Hukum di

Indonesia Pada Akhir Abad Ke-20.

Bandung: Alumni. 2006.

Ibrahim, Johnny. Teori dan Metodologi

Penelitian Hukum Normatif. Malang:

Bayumedia, 2005.

Lamintang, P.A.F. dan Theo Lamintang.

Kejahatan Melanggar Norma

Kesusilaan dan Kepatutan. Jakarta:

Sinar Grafika, 2009.

Mansur, Didik M Arif dan Elisatris Gultom.

Urgensi Perlindungan Korban

Kejahatan Antara Norma dan Realita.

Jakarta: Rajawali Pers, 2006.

Marlina. Peradilan Pidana Anak Di Indonesia.

Medan: Refika Aditama, 2009.

Marzuki, Peter Mahmud. Penelitian Hukum.

Jakarta: Kencana, 2007.

Mulyadi, Lilik. Kompilasi Hukum Pidana dalam Perspektif Teori dan Praktik.

Bandung: Mandar Maju, 2007.

Nasution, Bahder Johan. Negara Hukum Dan

Hak Asasi Manusia. Bandung: Mandar Maju, 2014.

Packer, Herbert L. The Limits of Criminal Sanction. California: Standford University Press, 1968.

Purnianti dan Rita Serena Kalibonso. Menyikapi Tirai Kekerasan Dalam
Rumah Tangga. Jakarta: Mitra Perempuan, 2003.

Sahetapy J.E. dkk. Bunga Rampai Viktimisasi. Bandung: Eresco, 1995.

Schafer, Stephen. The Victims and His Ciminal. New York: Randon House, 1968.

Soetedjo, Wagiati dan Melani. Hukum Pidana Anak. Bandung: Refika Aditama, 2013. Yulia, Rena. Viktimologi perlindungan hukum terhadap korban kejahatan. Yogyakarta: Graha Ilmu, 2010.

\section{Jurnal}

Dowden, C., \& Andrews, D. A.. Effective correctional treatment and violent re-offending: A meta-analysis.Canadian Journal of Criminology 42, (2000): 449-476.

Dwiatmodjo, Haryanto. "Pelaksanaan Perlindungan Hukum Terhadap Anak yang Menjadi Korban Tindak Pidana di Wilayah Hukum Pengadilan Negeri Banyumas". Jurnal Dinamika Hukum, Vol. 11, No. 2, (Mei 2011): 202.

Jr, William L Barnes. "Revenge on Utilitarianism: Renaouncing A Comprehensive economics Theory of Crime and Phunisment". Indiana Law Journal, Vol. 74, No. 627, (1999).

\section{Peraturan Perundang-undangan}

Peraturan Pemerintah No. 4 Tahun 2008 tentang Pemberian Kompensasi, Restitusi dan bantuan terhadap saksi 
dan korban.

Undang-undang Nomor 23 tahun 2002 tentang Perlindungan Anak.

Undang-undang Nomor 13 tahun 2006 tentang Perlindungan Saksi dan Korban.

Undang-undang Nomor 11 Tahun 2012 tentang Sistem Peradilan Pidana Anak.

Undang-Undang Republik Indonesia Nomor 31 Tahun 2014 tentang Perubahan Atas Undang-Undang Nomor 23 tahun 2002 tentang Perlindungan Anak.

Undang-Undang Republik Indonesia Nomor 35 Tahun 2014 tentang Perubahan Atas Undang-undang Nomor 13 tahun 2006 tentang Perlindungan Saksi dan Korban.

\section{Naskah Internet}

Komnas " Perempuan. "15 Jenis Kekerasan Seksual”. http://www. komnasperempuan.or.id/wp-content/ uploads/2013/12/15-Jenis-KekerasanSeksual_2013.pdf. Diakses 17 Januari 2017.

Komnas Perempuan. "Kekerasan Seksual". http://www.komnasperempuan.or.id/ publikasi/Indonesia/kampanye $\% 20$ 2012/Kekerasan\%20Seksual-\%20 Kenali\%20dan\%20 Tangani\%20_\%20 15\%20Bentuk.pdf. Diakses 17 Januari 2017.

Komisi Perlindungan Anak Indonesia. "Indonesia Darurat Kejahatan Seksual Anak". http://www.kpai.go.id/berita/ indonesia-darurat-kejahatan-seksualanak/. Diakses 17 Januari 2017. 